\title{
Dry Biomass of the Amazonian Macrophyte Paspalun Repens for Evaluation as Adsorbent Material of Heavy Metals $\mathrm{Zn}$ and $\mathrm{Cu}$
}

\author{
Solenise Pinto Rodrigues Kimura ${ }^{a}$, Rosimary Rodrigues dos Santos ${ }^{a}$, \\ João Christian Paixão Fonseca a, Joyce Alves da Silva ${ }^{a}$, Raimundo Nonato Alves da Silva ${ }^{a}$, \\ José Costa de Macêdo Neto ${ }^{a}$,João Evangelista Neto ${ }^{a}$, Bruno Mello de Freitas ${ }^{a}$, Domitila Pascoaloto ${ }^{b}$ \\ ${ }^{a}$ Departamento de Engenharia de Materiais, Universidade do Estado do Amazonas, Av. Darcy Vargas, \\ 1200, 69065-020, Manaus, AM, Brazil \\ ${ }^{b}$ Instituto Nacional de Pesquisas da Amazônia, Av. André Araújo, 2936, Manaus, AM, Brazil
}

Received: January 17, 2016; Revised: September 1, 2017; Accepted: October 5, 2017

\begin{abstract}
The present work aims at the preliminary evaluation of the Paspalun repens macrophyte dry biomass adsorbent material of zinc $(\mathrm{Zn})$ and copper $(\mathrm{Cu})$ metals from water. The diversity of Species is due to the extensive aquatic environment where it is inserted. The Paspalun repens species comes from the Buiuçu lake located in the region of Parintins-Amazonas- Brazil. The macrophyte was dried in a mill and then a digestion through biomass microwaves was done before and after its exposure to the solutions containing different concentrations of zinc and copper $\left(1.00,1.50,2.00,3.00 \mathrm{mg} \mathrm{mL}^{-1}\right.$ of metals) for a period of 48 hours. As a source of the metals, zinc sulfate $\left(\mathrm{ZnSO}_{4} 7 \mathrm{H}_{2} \mathrm{O}\right)$ for zinc, and copper sulfate $\left(\mathrm{CuSO}_{4} 5 \mathrm{H}_{2} \mathrm{O}\right)$ for copper were used as the source. As a result, the efficiency of Paspalun repens was observed in the metals removal, the highest removal percentage, of 29.67 and $37.07 \%$ in the leaves, whereas in the root it was 25.25 and $32.84 \%$ (at the concentration 1.0 and 2.0 $\mathrm{mg} / \mathrm{mL}$ consequently), was of zinc, therefore the dry biomass of this species can be considered as a low cost alternative material in the removal of these heavy metals, contributing to the improvement of water quality.
\end{abstract}

Keywords: aquatic macrophyte, heavy metals, dry biomass

\section{Introduction}

The indiscriminate use of natural resources has caused serious problems of contamination of the ecosystem, mainly due to the chemical pollution of organic and inorganic origin. Wastes with high concentrations of heavy metals require special attention due to their level of danger and the possibility of contamination of groundwater and water courses, making them often unfit for ingestion or costly in relation to abstraction, transport, treatment and distribution. The need to remove these pollutants from liquid effluents is fundamental so that metallic ions are not released into the receiving bodies in concentrations above the standards allowed by the current environmental legislation ${ }^{1}$. This situation has aroused in the authorities a great environmental concern and the need to elaborate effective measures to minimize $\mathrm{it}^{2}$. In this way, environmental legislation becomes increasingly restrictive in relation to the maximum limits allowed for the release of pollutants into the environment ${ }^{3}$.

The diversified use over adsorbents which contemplate for efficiency in adsorption processes demonstrates a wide variant in conventional treatment methods for the removal of heavy metals from the liquid effluent. Chemical processes

*e-mail: solenisekimura@yahoo.com.br such as chemical oxidation, chemical precipitation and chemical reduction, membrane technologies, ion exchange (columns or resins), processes of physical separation such as filtration and sedimentation, electrochemical and sorption processes are highlighted ${ }^{2}$. Considering that these methods are not always efficient, it is interesting to look for alternative and technically more viable technologies when compared to conventional techniques.

The adsorption phenomenon is described as a separation process where constituents present in a fluid stream (adsorbate) are retained on the surface of a porous solid (adsorbent). Studies show that, among the existing adsorbent materials, biomasses, and in particular aquatic macrophytes, present great ability in the removal of pollutants, being well studied for the treatment of domestic and industrial effluents ${ }^{3,1}$.

The biomasses, active and dead of macrophytes, are characterized by having functional groups in their structures that attribute them a great affinity with metallic ions. The selective affinity that metals have with the groups belonging to the surface of the biomass permits the metal/biomass interactions, which can reduce the costs of the process.

Considering the toxic effect of metals, zinc is capable of forming complexes with many organic and inorganic binders ${ }^{4}$. Under anaerobic conditions, and in the presence of 
sulphides, the precipitation of zinc limits its mobility. The mobility of zinc in soil is determined by the same factors that influence its transport in the aquatic environment, that is, the solubility of its compounds, $\mathrm{pH}$ and salinity ${ }^{5}$.

For humans, copper is one of the least toxic metals, and can be considered non-toxic in several exposure situations, due to its amphoteric character ${ }^{6}$. The excessive copper absorption by man can result in Wilson's disease, in which copper excess is deposited in the brain, pancreas, bones, myocardium, and liver ${ }^{7}$.

In this work, the dry biomass of the Paspalun repens macrophyte was used as adsorbent, which is an aquatic herb of the poaceae family, of free habit emerged. It presents growth of its branches and rhizomes at great distances into the water, eventually they break off and form islands that continue to grow, reaching large expanses ${ }^{8}$. In another study, the species Paspalum scrobiculatum was studied as an adsorbent in textile dye effluents ${ }^{9}$, demonstrating its potential in the removal of other pollutants.

The choice for the adsorbent is due to the fact that macrophytes have a large capacity to remove metallic ions from effluents, besides being renewable and biodegradable ${ }^{10}$.

\section{Materials and Methods}

The study site called Buiuçú Lake is part of the largest river system in the world, the Amazon Basin, known for its great territorial extension, its vast biodiversity and the size of its hydrographic network.

Individuals of the Paspalun repens species were collected at Buiuçú Lake, in the region of Parintins/AM, under the geographical coordinates: latitude $2^{\circ} 40 ' 5.20$ " and longitude $56^{\circ} 42^{\prime} 7.18$ ".

The macrophytes were separated into roots and leaves, oven dried with air circulation for 72 hours at $55^{\circ} \mathrm{C}$, then passed through a mill with a $1 \mathrm{~mm}$ coupled sieve.

For the determination of $\mathrm{Cu}$ and $\mathrm{Zn}$ metal concentrations, the dry biomass was digested before and after the experiment, and after reading the atomic absorption spectrophotometer, the equipment used was a Perkin Elmer Atomic Absorption Spectrophotometer, Model 1100B, that uses a specific lamp for each metal. The solutions containing the metals were prepared from the analytical reagents zinc sulfate $\left(\mathrm{ZnSO}_{4} \cdot 7 \mathrm{H}_{2} \mathrm{O}\right)$ and for copper, copper sulphate $\left(\mathrm{CuSO}_{4} \cdot 5 \mathrm{H}_{2} \mathrm{O}\right)$. Solutions were prepared with the following concentrations: $1.00 ; 1.50 ; 2.00$; $3.00 \mathrm{mg} \mathrm{mL}^{-1}$ of the metals ( $\mathrm{Cu}$ and $\mathrm{Zn}$ ).

The solutions containing the metals were packed in polyethylene containers. In each vessel, $1.00 \mathrm{~L}$ of solution and $10 \mathrm{~g}$ of the macrophyte dry biomass were placed in bags made of nylon fabric. At time intervals (1, 2, 3, 6, 12, 24, 36 and $48 \mathrm{~h}$ ), aliquots were collected from the aqueous solutions after the installation of the experiment ${ }^{11}$. After 48 hours of the experiment, the biomass was dried in an oven with air circulation for $48 \mathrm{~h}$ at $65^{\circ} \mathrm{C}$, comminuted and proceeded with the digestion in the microwave for the heavy metals reading. Infrared spectroscopy with Fourier transform (FTIR) analysis was performed on a Thermo Scientific brand equipment, model Nicolet 6700 , the measurement made in ATR mode using the Smart Omni Sampler accessory, in the region range of 675 to $4000 \mathrm{~cm}^{-1}$ and $4 \mathrm{~cm}^{-1}$ resolution.

\section{Results and Discussion}

Tables 1 and 2 show the initial and final concentrations of zinc and copper metals in the solution that remained in contact with the biomass. In all cases it is possible to observe the biomass efficiency in the removal of the metals when compared to different treatments, which is maintained with the addition of the concentrations. The values are presented in terms of removal percentage of the metals in the solution, ranging from 1.0 to $2.00 \mathrm{mg} \mathrm{mL}^{-1}$ for solution containing zinc (Table 1) and 1.00 to $3.00 \mathrm{mg} \mathrm{mL}^{-1}$ for copper solution (Table 2), demonstrating the efficiency of Paspalun repens in the removal of both metals.

Table 1 shows the percentages of zinc removal in the parts of the macrophyte (leaf and root), in which the leaf was the one that most absorbed this metal at all concentrations. It is known the ability of aquatic macrophytes in the removal of metals in solutions, and in most cases these elements are concentrated in the root because the translocation process for the aerial parts is usually slow ${ }^{12}$. However, Papalun repens presented an inverse behavior in this study. The absorbed percentages are higher for the leaves $29.67 ; 33.33$ and $37.07 \%$ for treatments with $1.00 ; 1.50$ and $2.00 \mathrm{mg}$ $\mathrm{mL}^{-1}$ respectively, while the root removed $25.25 ; 28.28$ and $32.84 \%$ at the same concentrations.

In a similar way, copper (Table 2) showed the highest removal in the leaf except for the concentration $3.00 \mathrm{mg} \mathrm{mL}^{-1}$, which had a lower value than that obtained by the root. The accumulation of some metals, among them copper and zinc in the Typha and Persicaria macrophytes, which showed high concentrations mainly in the root, concluding that these metals were essential for the survival of the species ${ }^{13}$. The accumulation capacity of the metals in the macrophyte is due to the interactions of several factors such as adsorption, absorption, interaction with metabolic sites, etc., and each mechanism has not only the biological characteristics of the macrophyte, but also the conditions of the medium ${ }^{12}$.

Figure 1 (a) and (b) show the concentration of $\mathrm{Zn}$ in the treatments according to the different sampling times of the solution. We can observe graphically that the best absorption time in which the maximum removal of the metals occurred varied in the interval of up to 12 hours for the concentrations 1.5 and $2.0 \mathrm{mg} \mathrm{mL}$, from that period, it is seen a constancy, that can be attributed to saturation of the biomass, demonstrating the efficiency of metal removal in that time interval. For the concentration $1.0 \mathrm{mg} \mathrm{mL}^{-1}$ the removal occurred within the first three hours (Figure 1a). 
Table 1. Zinc metal removal percentage of the initial and final concentrations of treatments for leaf and root.

\begin{tabular}{|c|c|c|c|c|c|}
\hline \multirow{2}{*}{ Metal } & \multirow{2}{*}{ Part } & \multirow{2}{*}{ Treatment } & \multicolumn{3}{|c|}{ Concentration $(\mathrm{mg} / \mathrm{mL})$} \\
\hline & & & 1.00 & 1.50 & 2.00 \\
\hline \multirow{6}{*}{$\mathrm{Zn}$} & \multirow{3}{*}{ Leaf } & Initial & 0.91 & 1.53 & 2.05 \\
\hline & & Final & 0.64 & 1.02 & 1.29 \\
\hline & & $\% \mathbf{R}$ & 29.67 & 33.33 & 37.07 \\
\hline & \multirow{3}{*}{ Root } & Initial & 0.99 & 1.45 & 2.04 \\
\hline & & Final & 0.74 & 1.04 & 1.37 \\
\hline & & $\% \mathrm{R}$ & 25.25 & 28.28 & 32.84 \\
\hline
\end{tabular}

$\% \mathrm{R}$ - percentage removal of metals in solution

Table 2. Metal removal percentage copper concentrations in the initial and final treatments of the leaf and root

\begin{tabular}{|c|c|c|c|c|c|}
\hline \multirow{2}{*}{ Metal } & \multirow{2}{*}{ Part } & \multirow{2}{*}{ Treatment } & \multicolumn{3}{|c|}{ Concentration $(\mathrm{mg} / \mathrm{mL})$} \\
\hline & & & 1.00 & 2.00 & 3.00 \\
\hline \multirow{6}{*}{$\mathrm{Cu}$} & \multirow{3}{*}{ Leaf } & Initial & 1.02 & 1.77 & 3.06 \\
\hline & & Final & 0.78 & 1.19 & 2.09 \\
\hline & & $\% \mathbf{R}$ & 23.53 & 32.77 & 31.70 \\
\hline & \multirow{3}{*}{ Root } & Initial & 0.98 & 1.93 & 3.03 \\
\hline & & Final & 0.77 & 1.36 & 2.05 \\
\hline & & $\% \mathbf{R}$ & 21.43 & 29.53 & 32.34 \\
\hline
\end{tabular}

$\% \mathrm{R}$ - percentage removal of metals in solution

西
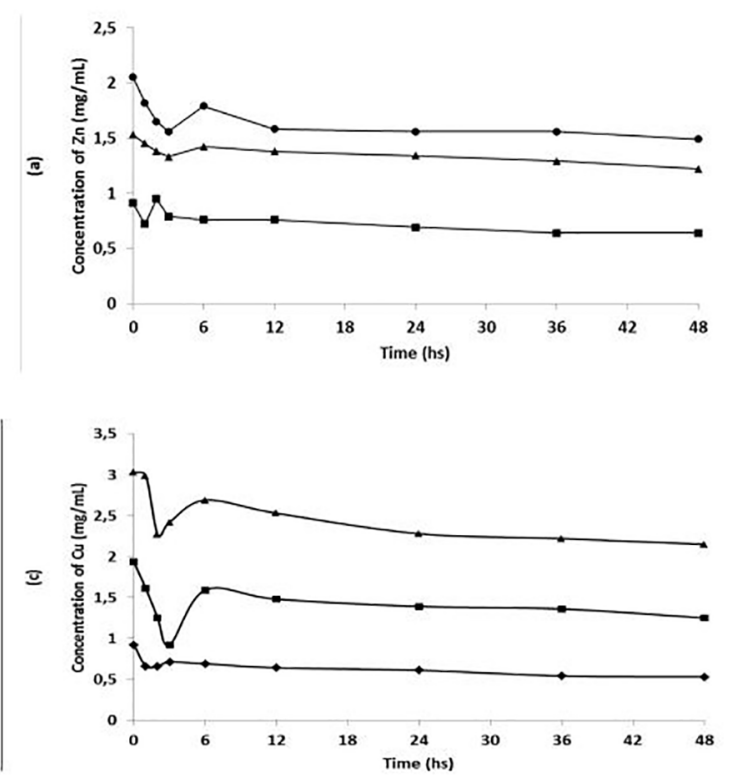

ㅍ.

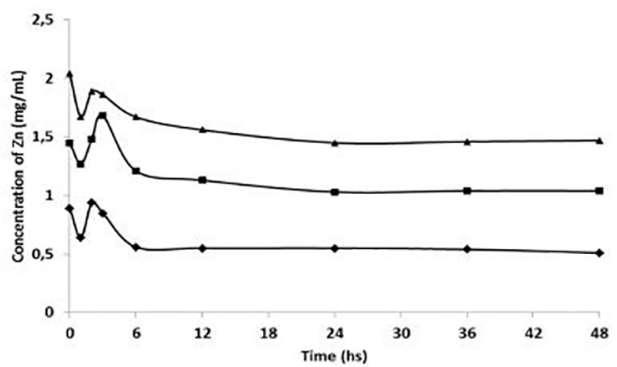

으

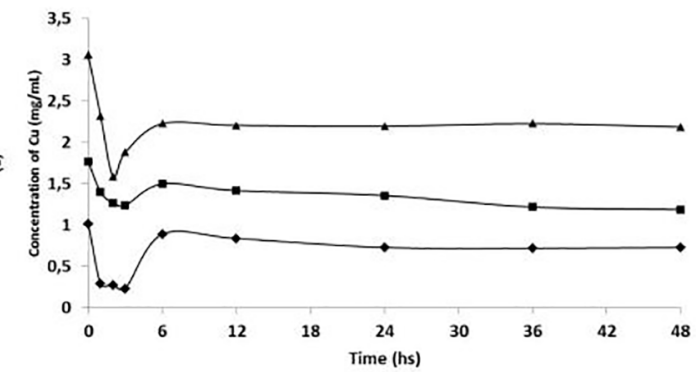

Figure 1. Concentration of $\mathrm{Zn}$, (a) leaf, (b) root and $\mathrm{Cu}$ (c) leaf, (d) root in different treatments as a function of time counted with biomass. 


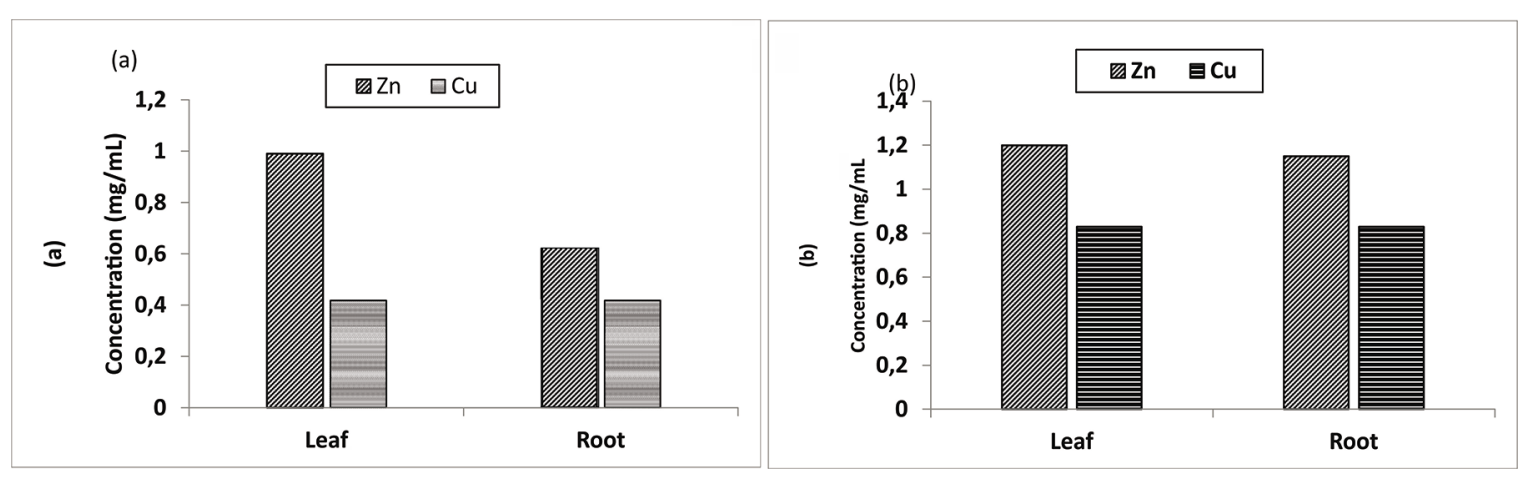

Figure 2. Accumulation of $\mathrm{Zn}$ and $\mathrm{Cu}$ in the dry biomass at concentrations $1.0 \mathrm{mg} \mathrm{mL}^{-1}$ (a) and $2.0 \mathrm{mg} \mathrm{mL}^{-1}$ (b).

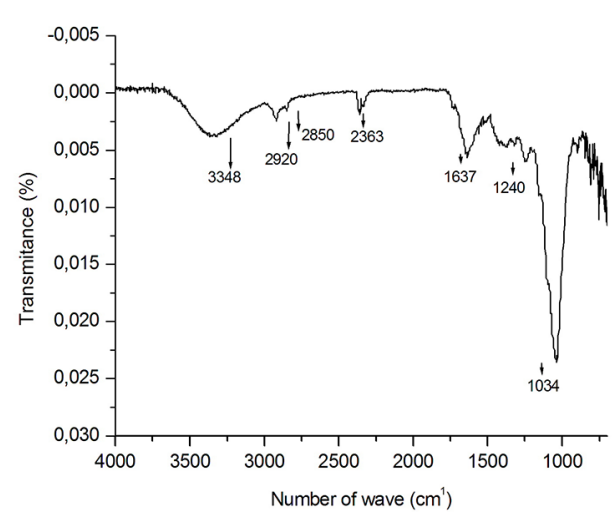

Figure 3. FTIR spectrum of the Paspalun repens leaf before exposure with the solution containing the metals.

For $\mathrm{Cu}$ (Figure 1c, d), it is observed that the time that the maximum removal of the metal takes place is of $12 \mathrm{~h}$ demonstrating more efficiency of the biomass for its absorption, besides having a higher rate of removal, as shown in the Tables 1 and 2, demonstrating that the biomass under study can be efficient due to its bioaccumulative potential.

The dry biomass of the Paspalun repens species demonstrated efficiency in the removal of $\mathrm{Zn}$ (Figure 2a) accumulating the metals in its tissues mainly in the leaf. In general, it can be seen from the graphs in Figure 2 that after approximately six hours of contact with the solutions containing the metals, the biomass saturates, we can consider that the optimal adsorption time is six hours. The graph also shows that the retention of the metal in the biomass is in agreement with the increase in the concentration in the solution.

\subsection{Identification of functional groups - FTIR}

In the FTIR analysis (Figure 3), the strong peak 3348 $\mathrm{cm}^{-1}$ is attributed to $\mathrm{OH}$ stretch vibration, the peak near $2924-2850 \mathrm{~cm}^{-1}$ is the asymmetric and symmetrical vibration of the methylene $\left(=\mathrm{CH}_{2}\right)$, respectively. The presence of the $2363 \mathrm{~cm}^{-1}$ band is probably attributed to the $(-\mathrm{COO})^{14}$ group, the peak near $1637 \mathrm{~cm}^{-1}$ is the absorption range of amide II, peak $1240 \mathrm{~cm}^{-1}$ is attributed to alcohol $\mathrm{CO}$ and peak 1034 $\mathrm{cm}^{-1}$ is the stretching vibration of $\mathrm{COH}$.

In the aquatic plants, the removal of heavy metals from liquid effluents occurs mainly by ion exchange attributed to the presence of carboxyl groups (R-COO-) that are present on the surface of plants. Of course, these sites are linked to cations $\left(\mathrm{H}^{+}, \mathrm{Na}^{+}, \mathrm{K}^{+}, \mathrm{Ca}^{+2}, \mathrm{Mg}^{+2}, \mathrm{Fe}^{+2}\right.$, however, in the presence of metals such as $\mathrm{Cu}^{+2}, \mathrm{Zn}^{+2}, \mathrm{Ni}^{+2}, \mathrm{Cd}^{+2}, \mathrm{~Pb}^{+2}, \mathrm{Cr}^{+3}$ there is a tendency for substitution between metals ${ }^{15,16}$, which may explain the absorption of the metals in the leaf and root (Figure 2) of Paspalun repens macrophyte. FTIR results showed that dry biomass has different functional groups available for binding of heavy metal ions, such as carboxyl, phosphate, amide and hydroxide.

\section{Conclusion}

Preliminary data show that Paspalun repens has considerable potential for the removal of metallic ions. The results showed higher macrophyte efficiency in the removal of copper. The leaf was the part that presented greater efficiency in the retention of zinc.

The FT-IR results showed the presence of different groups of carboxyl, amide, hydroxide functional groups, these groups are capable of reacting with metal ions in aqueous solution.

Dry biomass can be used as an adsorbent for the treatment of wastewater containing the metals zinc and copper, it is an abundant natural environmental biomass and may be an alternative for more expensive materials, such as activated carbon.

\section{Acknowledgment}

The authors would like to thank FAPEAM for its financial support and INPA for its technical support.

\section{References}

1. Lima LKS. Bioadsorção de ions metálicos em sistemas simples e competitivos preparados a partir de diferentes macrófitas. [Tese] Campinas: Universidade Estadual de Campinas (UNICAMP); 2015. 
2. Pietrobelli JMTA. Avaliação do potencial de biossorção dos ions $\mathrm{Cd}$ (ii), $\mathrm{Cu}$ (ii) e Zn (ii) pela macrófita egeria densa. [Dissertação]. Toledo: Universidade Estadual do Oeste do Paraná, UNIOESTE; 2007.

3. Brasil. Conama - Conselho Nacional de Meio Ambiente. Resolução $N^{o} 357$, de 17 de março de 2005. Dispõe sobre a classificação dos corpos de água e diretrizes ambientais para o seu enquadramento, bem como estabelece as condições $e$ padrões de lançamento de efluentes, e dá outras providências. Brasília: Diário Oficial da União; 2005.

4. Tanaka RH. Levantamento da ocorrência de plantas aquáticas nos reservatórios da CESP. São Paulo: CESP Report; 2000. $25 \mathrm{p}$.

5. Tavares CRG, Cossich ES, Silva EA, Ravagnani TMK. Problemas Ambientales com Soluciones Catalíticas - I. El cromo em el curtido de pieles. In: Ciência Y Tecnologia para el Desarrollo, Cooperacion Iberoamericana; 2001. p. 145-171.

6. Almeida Neto AF. Caracterização e avaliação de argilas como adsorventes na remoção e eluição de íons cobre e mercúrio em diferentes sistemas. [Tese]. Campinas: Universidade Estadual de Campinas (UNICAMP); 2011.

7. Thomaz SM. Explosões populacionais de plantas aquáticas: sintoma de um problema. In: Workshop de Controle de Plantas Aquáticas. Brasília; 1998. p. 16-17.

8. Tobin JM, White C, Gadd GM. Metal accumulation by fungi: Applications in environmental biotechnology. Journal of Industrial Microbiology. 1994;13(2):126-130.
9. Chandanshive VV, Rane NR, Tamboli AS, Gholave AR, Khandare RV, Govindwar SP. Co-plantation of aquatic macrophytes Typha angustifolia and Paspalum scrobiculatum for effective treatment of textile industry effluent. Journal of Hazardous Materials. 2017;338:47-56

10. Tobin JM, Roux JC. Mucor biosorbent for chromium removal from tanning effluent. Water Research.1998;32(5):1407-1416.

11. Gonçalves Junior AC, Selzlein C, Nacke H. Uso de biomassa seca de aguapé (Eichornia crassipes) visando à remoção de metais pesados de soluções contaminadas. Acta Scientiarum. Technology. 2009;31(1):103-108.

12. Kabata-Pendias A, Pendias H. Trace Elements in soils and plants. $3^{\text {rd }}$ ed. Boca Raton: CRC Press; 2001.413 p.

13. Cardwell AJ, Hawker DW, Greenway M. Metal accumulation in aquatic macrophytes from southeast Queensland, Australia. Chemosphere. 2002;48(7):653-663.

14. Saygideger S, Gulnaz O, Istifli ES, Yucel N. Adsorption of $\mathrm{Cd}(\mathrm{II}), \mathrm{Cu}(\mathrm{II})$ and $\mathrm{Ni}(\mathrm{II})$ ions by Lemna minor L.: Effect of physicochemical environment. Journal of Hazardous Materials. 2005;126(1-3):96-104.

15. Guilherme LRG, Marques JJ, Pierangeli MAP, Zuliani DQ, Campos ML, Marchi G. Elementos-traço em solos e sistemas aquáticos. In: Torrado-Vidal P, Alleoni LRF, Cooper M, Silva AP, eds. Tópicos em Ciência do Solo. Viçosa: Sociedade Brasileira de Ciência do Solo; 2005. p. 345-390.

16. Schneider IAH, Rubio J, Smith RW. Biosorption of metals onto plant biomass: exchange adsorption or surface precipitation? International Journal of Mineral Processing. 2001;62(1-4):111120. 